\title{
Discovery of imatinib-responsive FIP1L1-PDGFRA mutation during refractory acute myeloid leukemia transformation of chronic myelomonocytic leukemia
}

\author{
Shilpan Shah', Sanam Loghavi ${ }^{2}$, Guillermo Garcia-Manero ${ }^{1}$ and Joseph D Khoury²*
}

\begin{abstract}
The FIP1L1-PDGFRA rearrangement results in constitutive activation of the tyrosine kinase PDGFRA. Neoplasms harboring this rearrangement are responsive to imatinib mesylate at doses much lower than those recommended for the treatment of chronic myelogenous leukemia. Only a single report has described the identification of FIPIL1-PDGFRA in chronic myelomonocytic leukemia (CMML). Herein, we present a case report of a patient in whom the FIP1L1-PDGFRA was discovered as he evolved from CMML to acute myeloid leukemia (AML). The presence of a dominant neoplastic clone with FIPIL1-PDGFRA rearrangement was suspected on the basis of sudden onset of peripheral and bone marrow eosinophilia and confirmed by fluorescence in situ hybridization and molecular diagnostic tests. Whereas the patient was initially refractory to chemotherapy before the rearrangement was detected, subsequent therapy with imatinib led to complete remission.
\end{abstract}

Keywords: FIP1L1-PDGRFA, Chronic myelomonocytic leukemia, Imatinib mesylate

\section{Background}

Hypereosinophilia is a feature of a variety of uncommon hematologic disorders like hyperseosinophilic syndrome (HES), systemic mastocytosis (SM) and chronic eosinophilic leukemia (CEL). Approximately $4 \%$ of patients with HES or SM have interstitial deletion of chromosome 4q12 leading to juxtaposition of FIP1L1 and PDGFRA [1]. The fusion product is exquisitely sensitive to therapy with imatinib mesylate, and hence its identification has important therapeutic ramifications particularly in hematologic disorders presenting with hypereosinophilia [2-5]. We herein present the case of a patient in whom FIP1L1-PDGFRA was discovered at the time of evolution from chronic myelomonocytic leukemia (CMML) to refractory acute myeloid leukemia and how therapy with imatinib resulted in durable complete remission.

\footnotetext{
* Correspondence: jkhoury@mdanderson.org

2Department of Hematopathology, The University of Texas MD Anderson Cancer Center, 1515 Holcombe Boulevard, MS-72, 77030 Houston, TX, USA Full list of author information is available at the end of the article
}

\section{Case presentation}

A 64-year-old Caucasian man presented to our institution with a 6-month history of progressive leukocytosis. Per the patient's outside medical records, a bone marrow biopsy at initial presentation had shown a $100 \%$ cellular marrow with marked myeloid hyperplasia. Conventional cytogenetics demonstrated a diploid male karyotype. Fluorescence in situ hybridization studies (FISH) were negative for myelodysplasia-associated abnormalities. Molecular studies were negative for $B C R-A B L$ rearrangement, and $J A K 2^{V 617 F}$ and MPL ${ }^{W 515 L}$ mutations. Based on these features, he was diagnosed with myelodysplastic/myeloproliferative neoplasm, unclassifiable, and was started on hydroxyurea, 1.5 grams daily. At presentation to our institution, his white blood cell (WBC) count was $44.6 \times 10^{9} / \mathrm{L}$ with $76 \%$ neutrophils, $6 \%$ metamyelocytes, $10 \%$ monocytes, $6 \%$ lymphocytes, $1 \%$ eosinophils and $1 \%$ blasts, with absolute monocytosis $\left(4.46 \times 10^{9} / \mathrm{L}\right)$ and eosinophilia $\left(0.45 \times 10^{9} / \mathrm{L}\right)$. He was anemic (hemoglobin $9.0 \mathrm{~g} / \mathrm{dL}$ ) and mildly thrombocytopenic (platelet count $119 \times 10^{9} / \mathrm{L}$ ). He did not have splenomegaly on physical examination. Bone marrow evaluation performed at presentation to our institution 

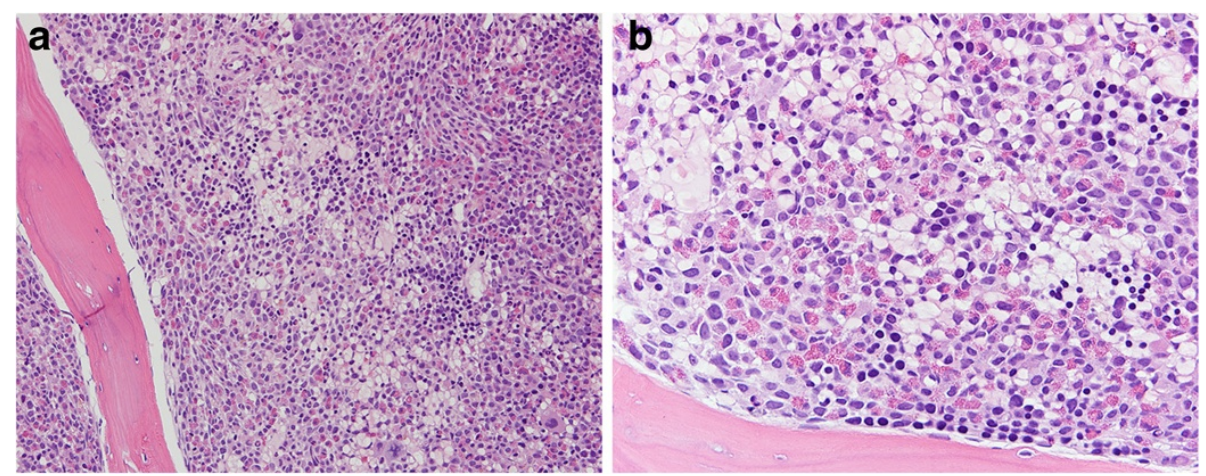

Figure 1 Bone marrow core biopsy at the time of initial FIP1L1- PDGFRA rearrangement discovery. The bone marrow is hypercellular (100\%), with prominent eosinophilia and myeloid hyperplasia, mild increase in immature cells, and features of myelofibrosis manifesting primarily as cellular streaming. (a: 10x objective; b: 20x objective; hematoxylin and eosin stain).

revealed a $100 \%$ cellular bone marrow with myeloid hyperplasia. Megakaryocytes were decreased in number and included rare dysplastic forms. Wright-Giemsa stained smears prepared from the bone marrow aspirate were remarkable for increased myeloid cells and trilineage dysplasia; a 500-cell differential count showed mildly increased monocytes (6\%) and myeloid blasts (7\%). The constellation of findings was diagnostic of chronic myelomonocytic leukemia (CMML-1). Conventional cytogenetics showed trisomy 8 in two of twenty analyzed metaphases; this was confirmed by fluorescence in situ hybridization (FISH) using an alphasatellite (D8Z2) CEP8 probe (positive in $4 \%$ of the cells studied). Reverse transcriptase polymerase chain reaction (RT-PCR) performed on the bone marrow aspirate was negative for $B C R-A B L$ fusion. Targeted next-generation sequencing mutation analysis was negative for 53 "hotspot" mutations analyzed as described previously [6].

The patient was enrolled on the SGI-110 clinical trial, a phase 1-2 dose escalation, multicenter study of SGI-110, a DNA hypomethylating agent, in subjects with intermediate or high-risk myelodysplastic syndromes (MDS) or AML. He received two courses of SGI-110, after which he experienced rapidly progressive leukocytosis with a peak WBC count of $126 \times 10^{9} / \mathrm{L}$ and new onset of peripheral eosinophilia (11\%). Bone marrow evaluation performed at this time demonstrated nearly $100 \%$ cellularity with myeloid hyperplasia; in contrast to the previous biopsy, prominent eosinophilia and moderate myelofibrosis were noted in this sample (Figure 1a-b). Wright-Giemsa stained smears showed increased granulocytes with leftshifted maturation and prominent eosinophilia (16\%) in a background of trilineage dysplasia. There was no significant increase in bone marrow monocytes (5\%). Myeloid blasts comprised $12 \%$ of total nucleated cells. The unexpected and abrupt presence of prominent eosinophilia in the peripheral blood and bone marrow at this point in time prompted us to evaluate for PDGFRA rearrangement. FISH analysis performed using a LSI-4q12 tricolor rearrangement probe that hybridizes to the chromosome 4q12 region containing the FIP1L1, CHIC2 and PDGFRA genes revealed deletion of the CHIC2 gene in $86.5 \%$ of the cells analyzed indicating the presence of the FIP1L1-PDGFRA rearrangement. The FIP1L1-PDGFRA fusion transcript was further confirmed by RT-PCR. Lowlevel trisomy 8 was also detected by FISH in this sample. Based on these findings a diagnosis of myelodysplastic/myeloproliferative neoplasm with eosinophilia and PDGFRA rearrangement was rendered. A follow-up bone marrow biopsy after one month showed acute myeloid leukemia with

Table 1 Sequence of clinical events

\begin{tabular}{|c|c|c|c|c|c|c|c|}
\hline Event sequence & $\begin{array}{l}\text { WBC } \\
\left(\times 10^{9}\right)\end{array}$ & $\begin{array}{l}\text { Eosinophils in } \\
\text { PB }(\%, A E C)\end{array}$ & $\begin{array}{l}\text { Eosinophils } \\
\text { in BM (\%) }\end{array}$ & $\begin{array}{l}\text { Blasts in } \\
\text { BM (\%) }\end{array}$ & Diagnosis & Intervention & $\begin{array}{l}\text { Disease } \\
\text { status }\end{array}$ \\
\hline Initial presentation & 44.6 & $1,0.45$ & 1 & 7 & CMML-1 & SGI-110 & Refractory \\
\hline After 2 months & 65.1 & $9,5.8$ & 5 & 4 & CMML-1 & SGI-110 & Progression \\
\hline After 1 month & 126 & $11,13.8$ & 16 & 12 & $\begin{array}{l}\text { Myelodysplastic/myeloproliferative } \\
\text { neoplasm with eosinophilia, } \\
\text { and PDGFRA rearrangement }\end{array}$ & $\begin{array}{l}\text { Fludarabine + } \\
\text { Cytarabine }\end{array}$ & Progression \\
\hline After 1 month & 6.4 & $1,0.06$ & 1 & 26 & AML with PDGFRA rearrangement & $\begin{array}{l}\text { Imatinib } \\
\text { (with Idarubicin + Cutarabine) }\end{array}$ & Remission \\
\hline
\end{tabular}

WBC: white blood cells, PB: peripheral blood, AEC: absolute eosinophil count, BM: bone marrow, CMML: chronic myelomonocytic leukemia, AML: acute myeloid leukemia. 
Table 2 PDGFRA rearrangement in unusual adult myeloid neoplasms

\begin{tabular}{|c|c|c|c|}
\hline Author/journal & Disease & Treatment & Outcome \\
\hline Tang et al., Acta Haematol 2012;128:83-87 & $\begin{array}{l}\text { Myeloproliferative neoplasm } \\
\text { with eosinophilia }\end{array}$ & $\begin{array}{l}\text { Imatinib - started at } 400 \mathrm{mg} \text { daily } \\
\text { and maintained at } 100 \mathrm{mg} \text { daily }\end{array}$ & $\begin{array}{l}\text { Complete hematologic and molecular } \\
\text { remission at } 12 \text { months }\end{array}$ \\
\hline Papanikolaou et al., Ann Hematol. 2012 May;91(5):785-7 & $\begin{array}{l}\text { Chronic eosinophilic leukemia with } \\
\text { lytic bone lesions }\end{array}$ & $\begin{array}{l}\text { Imatinib } 200 \text { mg daily; on progression, } \\
\text { nilotinib } 400 \text { mg BID }\end{array}$ & $\begin{array}{l}\text { Progressed to erythroblastoid blast } \\
\text { crisis after } 2 \text { years on TKI }\end{array}$ \\
\hline Sorour et al., Br J Haematol. 2009 Jul;146(2):225-7 & $\begin{array}{l}\text { Acute myeloid leukemia } \\
\text { with eosinophilia }\end{array}$ & $\begin{array}{l}\text { Imatinib with FLAG-Ida followed by } \\
\text { matched unrelated allograft }\end{array}$ & $\begin{array}{l}\text { Relapsed with Imatinib resistance; started } \\
\text { on Dasatinib but died } 15 \text { months later }\end{array}$ \\
\hline Lierman et al., Leukemia. 2009 May;23(5):845-51 & $\begin{array}{l}\text { Chronic eosinophilic leukemia } \\
\text { blast crisis with Imatinib resistance }\end{array}$ & Sorafenib 400 mg BID & $\begin{array}{l}\text { Hematologic response without } \\
\text { molecular response for } 3 \text { months }\end{array}$ \\
\hline Zota et al., J Clin Oncol. 2008 Apr 20;26(12):2040-1 & Chronic myelomonocytic leukemia & Imatinib 400 mg BID & $\begin{array}{l}\text { Resolution of eosinophilia without } \\
\text { other hematologic response; progressed to } \\
\text { extramedullary disease }\end{array}$ \\
\hline Florian et al., Leuk Res. 2006 Sep;30(9):1201-5 & $\begin{array}{l}\text { Systemic mastocytosis with chronic } \\
\text { eosinophilic leukemia }\end{array}$ & $\begin{array}{l}\text { Incomplete response to hydroxyurea, } \\
\text { corticosteroids and interferon-alpha; } \\
\text { started on imatinib } 100 \text { mg in } 2002\end{array}$ & $\begin{array}{l}\text { Long-term response to low-dose Imatinib } \\
(50-100 \mathrm{mg} \text { ) after inadequate responses } \\
\text { to previous therapies }\end{array}$ \\
\hline Von Bubnoff et al., Leukemia. 2005 Feb;19(2):286-7 & $\begin{array}{l}\text { Chronic myeloproliferative disorder } \\
\text { with eosinophilia }\end{array}$ & Imatinib 100-400 mg daily & $\begin{array}{l}\text { Hematologic and symptomatic response for } \\
6 \text { months; progression to myeloid blasts crisis } \\
\text { and malignant pleural effusion }\end{array}$ \\
\hline $\begin{array}{l}\text { Saflet et al., Genes Chromosomes Cancer } \\
2004 \text { May;40(1):44-50 }\end{array}$ & $\begin{array}{l}\text { Atypical chronic myeloid leukemia } \\
\text { with } t(4 ; 22) \text { leading to formation of } \\
\text { BCR-PDGFRA fusion gene }\end{array}$ & Imatinib 100 mg daily & $\begin{array}{l}\text { Complete hematologic response at 7-month } \\
\text { follow up }\end{array}$ \\
\hline
\end{tabular}


$26 \%$ blasts. In addition to persistent low-level trisomy 8, conventional cytogenetics and FISH demonstrated a new clone with TP53 gene deletion. FISH was positive for deletion of the CHIC2 gene, TP53 deletion and trisomy 8 in $90 \%, 10 \%$ and $9 \%$ of the analyzed cells, respectively.

The patient was then started on imatinib mesylate $400 \mathrm{mg}$ daily along with a short course of idarubucin and subcutaneous cytarabine for cytoreduction. He achieved complete hematologic and morphologic remission and went on to receive a matched unrelated allogeneic stem cell transplant (SCT). To date, the patient remains in complete hematologic, morphologic and molecular remission with successful engraftment as demonstrated by chimerism studies. The sequence of events is provided in Table 1.

\section{Discussion}

The PDGFRA and PDGFRB proteins are members of the class III receptor kinase family that also includes cKIT, and FLT3 [7]. PDGFRA is located on chromosome $4 \mathrm{q} 12$ [8]. A small interstitial deletion of $4 \mathrm{q} 12$ leads to juxtaposition of FIP1L1 and PDGFRA resulting in a gain of function fusion protein with signal independent kinase activity and therefore increased cell proliferation and survival [9]. This interstitial deletion is generally cryptic and not detectable using standard cytogenetic banding techniques.

FIP1L1- PDGFRA rearrangements are often associated with chronic eosinophilic leukemia and hypereosinophilic syndromes $[9,10]$ as well as systemic mastocytosis [11]. Pardanani et al. reported a prevalence of approximately $4 \%$ for FIP1L1- PDGFRA fusion gene in a large series of patients with suspected or established HES or systemic mastocysosis [1]. We recently described a case of chronic neutrophilic leukemia associated with FIP1L1- PDGFRA rearrangement [4]. The basis for the apparent lineage predilection of FIP1L1- PDGFRA for eosinophils is not well understood. The hypothesis is that it is present in all myeloid lineages, but that eosinophils are particularly sensitive to the FIP1L1- PDGFRA proliferative signal [12]. In contrast to rearrangements involving PDGFRB, the FIP1L1PDGFRA rearrangement is exceedingly rare in the setting of chronic myelomonocytic leukemia [13-16]. To our knowledge, only one other case has been reported in the literature by Zota et al. [17] In contrast to our patient, the patient reported by Zota et al. did not evolve in to acute myeloid leukemia, albeit the acquisition of FIP1L1PDGFRA fusion was considered a feature of disease evolution. Initiation of imatinib resolved eosinophilia but did not effectively improve other counts, and the patient subsequently progressed to CMML-2 and developed extramedullary disease in abdominal lymph nodes; she succumbed in 10 months. A case series from Germany described five patients with FIP1L1- PDGFRA who presented with AML and eosinophilia, but no history of antecedent myeloid malignancy was reported for any of the patients [18]. A summary of case reports describing PDGFRA rearrangements arising in patients with myeloid neoplasms commonly not associated with such rearrangements is provided in Table 2. All patients received imatinib therapy and achieved at least a hematologic response. One patient got sorafenib and another got dasatinib after acquiring resistance to imatinib. Two of eight patients maintained molecular response, while two maintained hematologic response at last reported follow up. Notably, clonal acquisition of FIP1L1-PDGFRA has not been reported in the setting of acute myeloid leukemia evolving from CMML.

Our case highlights the importance of assessing for PDGFRA rearrangement in myeloid neoplasms with de novo or subsequently acquired eosinophilia. The identification of the FIP1L1- PDGFRA fusion gene is significant since imatinib has excellent efficacy at low doses (100$400 \mathrm{mg}$ daily) in FIP1L1-PDGFRA-positive neoplasms $[2,5]$. Of note, due to the 250 -fold lower $\mathrm{IC}_{50}$ as compared to $B C R-A B L$, reports suggest that even once weekly doses of imatinib are adequate in the setting of FIP1L1-PDGFRA [3]. However, these responses are eventually lost due to emergence of an imatinib-resistant T614I mutation in the ATP-binding site of PDGFRA [9]. In our patient, the ability to induce a complete remission using imatinib at a time when the patient was unresponsive to chemotherapy induction permitted subsequent allogeneic SCT and an ensuing durable remission as of last follow up.

\section{Conclusion}

We describe a case report of a patient who transformed from CMML to AML which was refractory to standard chemotherapy. Emergence of peripheral and bone marrow hypereosinophilia during this transformation led to suspicion of presence of FIP1L1-PDGFRA rearrangement, which was confirmed by FISH and RT-PCR. Treatment with imatinib led to a complete remission and permitted allogeneic SCT therapy.

\section{Endnote}

The identification of new onset of eosinophilia in acute myeloid leukemia arising in a patient with chronic myelomonocytic leukemia might indicate acquisition of imatinib-responsive FIP1L1-PDGFRA rearrangement.

\section{Consent}

Granted under protocol approved by the Institutional Review Board of The University of Texas M.D. Anderson Cancer Center.

\section{Abbreviations}

CMML: Chronic myelomonocytic leukemia; AML: Acute myeloid leukemia; HES: Hyperseosinophilic syndrome; SM: Systemic mastocytosis; CEL: Chronic eosinophilic leukemia; FISH: Fluorescence in situ hybridization studies; PCR: Polymerase chain reaction; MDS: Myelodysplastic syndromes. 


\section{Competing interests}

The authors declare no competing interest pertaining related to this study.

\section{Authors' contributions}

SS, GGM and JDK: conception of manuscript, chart review, and manuscript preparation; SL: chart review and manuscript preparation. All authors have read and approved the final manuscript.

\section{Author details}

'Department of Leukemia, The University of Texas MD Anderson Cancer Center, 1515 Holcombe Boulevard, MS-72, 77030 Houston, TX, USA. 2Department of Hematopathology, The University of Texas MD Anderson Cancer Center, 1515 Holcombe Boulevard, MS-72, 77030 Houston, TX, USA.

Received: 24 February 2014 Accepted: 16 March 2014

Published: 27 March 2014

\section{References}

1. Pardanani A, Ketterling RP, Li CY, Patnaik MM, Wolanskyj AP, Elliott MA, Camoriano JK, Butterfield JH, Dewald GW, Tefferi A: FIP1L1-PDGFRA in eosinophilic disorders: prevalence in routine clinical practice, long-term experience with imatinib therapy, and a critical review of the literature. Leuk Res 2006, 30(8):965-70.

2. Helbig G, Stella-Holowiecka B, Grosicki S, Bober G, Krawczyk M, Wojnar J, Reiter A, Hochhaus A, Holowiecki J: The results of imatinib therapy for patients with primary eosinophilic disorders. Eur J Haematol 2006, 76(6):535-6.

3. Helbig G, Stella-Hołowiecka B, Majewski M, Całbecka M, Gajkowska J, Klimkiewicz R, Moskwa A, Grzegorczyk J, Lewandowska M, Hołowiecki J: A single weekly dose of imatinib is sufficient to induce and maintain remission of chronic eosinophilic leukaemia in FIP1L1-PDGFRAexpressing patients. Br J Haematol 2008, 141(2):200-4.

4. Jain N, Khoury JD, Pemmaraju N, Kollipara P, Kantarjian H, Verstovsek S. Imatinib therapy in a patient with suspected chronic neutrophilic leukemia and FIP1L1-PDGFRA rearrangement. Blood 2013, 122(19):3387-8.

5. Metzgeroth G, Walz C, Erben P, Popp H, Schmitt-Graeff A, Haferlach C, Fabarius A, Schnittger S, Grimwade D, Cross NC, Hehlmann R, Hochhaus A, Reiter A: Safety and efficacy of imatinib in chronic eosinophilic leukaemia and hypereosinophilic syndrome: a phase-Il study. Br J Haematol 2008, 143(5):707-15.

6. Alayed K, Patel KP, Konoplev S, Singh RR, Routbort MJ, Reddy N, Pemmaraju N, Zhang L, Shaikh AA, Aladily TN, Jain N, Luthra R, Medeiros LJ, Khoury JD: TET2 mutations, myelodysplastic features, and a distinct immunoprofile characterize blastic plasmacytoid dendritic cell neoplasm in the bone marrow. Am J Hematol 2013, 88(12):1055-61.

7. Reilly JT: Class III receptor tyrosine kinases: role in leukaemogenesis. $\mathrm{Br} J$ Haematol 2002, 116(4):744-57.

8. Gronwald RG, Adler DA, Kelly JD, Disteche CM, Bowen-Pope DF: The human PDGF receptor alpha-subunit gene maps to chromosome 4 in close proximity to c-kit. Hum Genet 1990, 85(3):383-5.

9. Cools J, DeAngelo DJ, Gotlib J, Stover EH, Legare RD, Cortes J, Kutok J, Clark J, Galinsky I, Griffin JD, Cross NC, Tefferi A, Malone J, Alam R, Schrier SL, Schmid J, Rose M, Vandenberghe P, Verhoef G, Boogaerts M, Wlodarska I, Kantarjian H, Marynen P, Coutre SE, Stone R, Gilliland DG: A tyrosine kinase created by fusion of the PDGFRA and FIP1L1 genes as a therapeutic target of imatinib in idiopathic hypereosinophilic syndrome. $N$ Engl J Med 2003, 348(13):1201-14.

10. Pardanani A, Brockman SR, Paternoster SF, Flynn HC, Ketterling RP, Lasho TL, Ho CL, Li CY, Dewald GW, Tefferi A: FIP1L1-PDGFRA fusion: prevalence and clinicopathologic correlates in 89 consecutive patients with moderate to severe eosinophilia. Blood 2004, 104(10):3038-45.

11. Pardanani A, Pardanani A, Ketterling RP, Brockman SR, Flynn HC, Paternoster SF, Shearer BM, Reeder TL, Li CY, Cross NC, Cools J, Gilliland DG, Dewald GW, Tefferi A: CHIC2 deletion, a surrogate for FIP1L1-PDGFRA fusion, occurs in systemic mastocytosis associated with eosinophilia and predicts response to imatinib mesylate therapy. Blood 2003, 102(9):3093-6.

12. Gotlib J: Molecular classification and pathogenesis of eosinophilic disorders: 2005 update. Acta Haematol 2005, 114(1):7-25.

13. Apperley JF, Gardembas M, Melo JV, Russell-Jones R, Bain BJ, Baxter EJ, Chase A, Chessells JM, Colombat M, Dearden CE, Dimitrijevic S, Mahon FX, Marin D, Nikolova Z, Olavarria E, Silberman S, Schultheis B, Cross NC, Goldman JM: Response to imatinib mesylate in patients with chronic myeloproliferative diseases with rearrangements of the platelet-derived growth factor receptor beta. N Engl J Med 2002, 347(7):481-7.

14. David M, Cross NC, Burgstaller S, Chase A, Curtis C, Dang R, Gardembas M, Goldman JM, Grand F, Hughes G, Huguet F, Lavender L, McArthur GA, Mahon FX, Massimini G, Melo J, Rousselot P, Russell-Jones RJ, Seymour JF, Smith G, Stark A, Waghorn K, Nikolova Z, Apperley JF: Durable responses to imatinib in patients with PDGFRB fusion gene-positive and BCR-ABLnegative chronic myeloproliferative disorders. Blood 2007, 109(1):61-4.

15. Drechsler M, Hildebrandt B, Kündgen A, Germing U, Royer-Pokora B: Fusion of H4/D10S170 to PDGFRbeta in a patient with chronic myelomonocytic leukemia and long-term responsiveness to imatinib. Ann Hematol 2007, 86(5):353-4.

16. La Starza R, Rosati R, Roti G, Gorello P, Bardi A, Crescenzi B, Pierini V Calabrese O, Baens M, Folens C, Cools J, Marynen P, Martelli MF, Mecucci C, Cuneo A: A new NDE1/PDGFRB fusion transcript underlying chronic myelomonocytic leukaemia in Noonan Syndrome. Leukemia 2007, 21(4):830-3.

17. Zota V, Miron PM, Woda BA, Raza A, Wang SA: Eosinophilia with FIP1L1PDGFRA fusion in a patient with chronic myelomonocytic leukemia. J Clin Oncol 2008, 26(12):2040-1.

18. Metzgeroth G, Walz C, Score J, Siebert R, Schnittger S, Haferlach C, Popp H, Haferlach T, Erben P, Mix J, Müller MC, Beneke H, Müller L, Del Valle F, Aulitzky WE, Wittkowsky G, Schmitz N, Schulte C, Müller-Hermelink K, Hodges E, Whittaker SJ, Diecker F, Döhner H, Schuld P, Hehlmann R, Hochhaus A, Cross NC: Recurrent finding of the FIP1L1-PDGFRA fusion gene in eosinophilia-associated acute myeloid leukemia and lymphoblastic T-cell lymphoma. Leukemia 2007, 21(6):1183-8.

doi:10.1186/1756-8722-7-26

Cite this article as: Shah et al: Discovery of imatinib-responsive FIP1L1-PDGFRA mutation during refractory acute myeloid leukemia transformation of chronic myelomonocytic leukemia. Journal of Hematology \& Oncology 2014 7:26.

\section{Submit your next manuscript to BioMed Central and take full advantage of:}

- Convenient online submission

- Thorough peer review

- No space constraints or color figure charges

- Immediate publication on acceptance

- Inclusion in PubMed, CAS, Scopus and Google Scholar

- Research which is freely available for redistribution

Submit your manuscript at www.biomedcentral.com/submit
C Biomed Central 